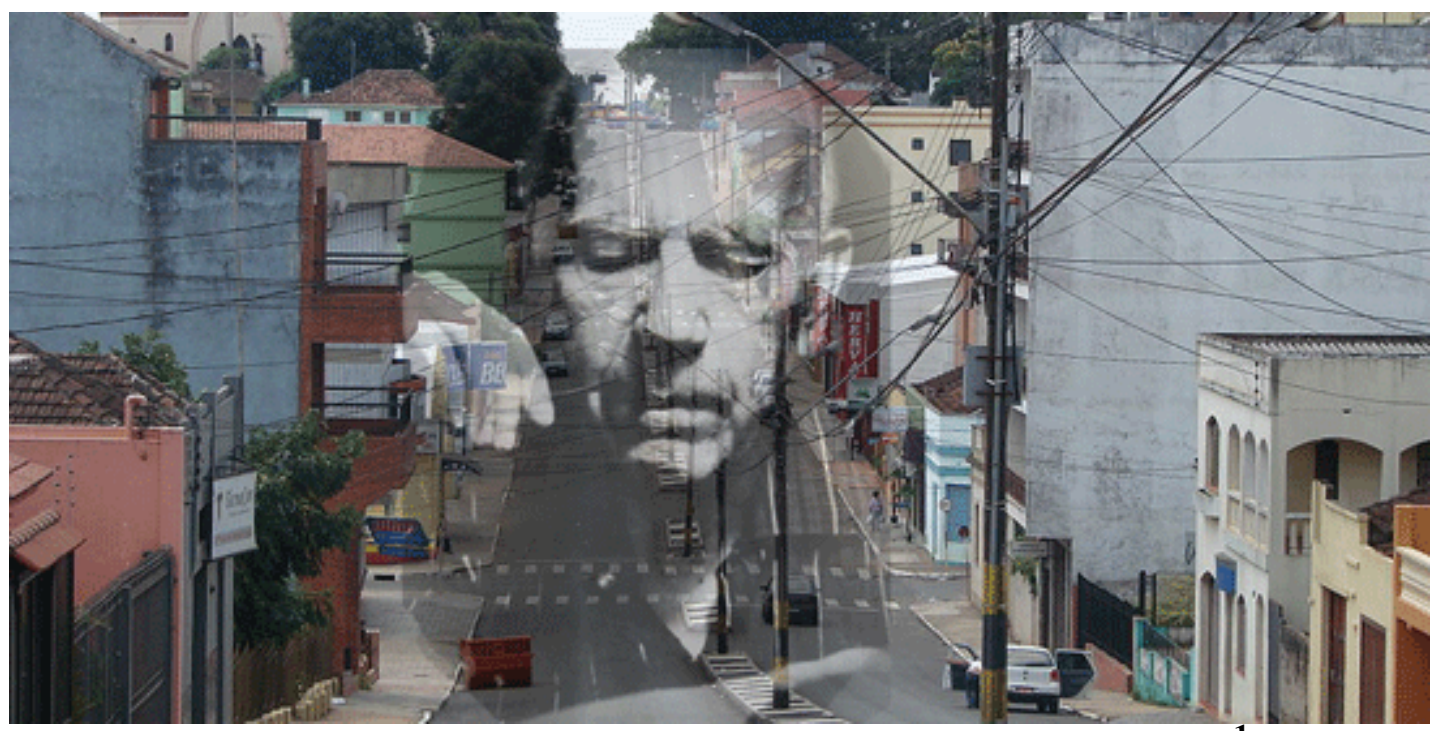

\title{
Rememoração/Comemoração no Discurso Urbano ${ }^{1}$
}

(Rememoration/Commemoration in the Urban Discourse)

Maria Cleci Venturini*

\section{Resumo}

Propomos, neste artigo, uma reflexão sobre a rememoração/comemoração no espaço urbano por meio de três noções: rememoração, comemoração e lugar de memória. Nosso objetivo é teorizar acerca da rememoração/comemoração como noção articulada pela memória discursiva. As três noções em questão são assim deslocadas dos domínios da História e da Antropologia para o funcionamento discursivo. A rememoração, nos dois primeiros domínios, é tratada como recordação; a comemoração é o lugar da celebração e o lugar de memória foi introduzido por Pierre Nora (1992) para funcionar como contramemória, o lugar da crítica. Discursivamente, a rememoração - discurso de - recobre e funciona como memória e a comemoração - discurso sobre - como intradiscurso. No eixo da formulação, elas funcionam juntas a partir da memória discursiva constitutiva do discurso urbano.

Palavras-chave: discurso urbano, memória, rememoração/comemoração

\begin{abstract}
In this work, we reflect upon the rememoration/commemoration in the urban space by means of three notions: rememoration, commemoration and place of memory. We dislocate these three notions from the History and Anthropology domains to the functioning of discourse. The first notion, in these same domains, is referred to as rememoration, the second, constitutes as a place for celebration and the third was coined by Pierre Nora (1992) to function as counter-memory, the place of criticism. Discursively, the rememoration - discourse of - recovers and functions as memory and commemoration - discourse about - as intradiscourse. In the axis of formulation, they function together from the discursive memory constitutive of the urban discourse. Our objective, in this article, is theorize in relation to rememoration/commemoration as a notion articulated by the discursive memory.
\end{abstract}

Keywords: urban discourse, memory, rememoration/commemoration

\footnotetext{
${ }^{1}$ As reflexões empreendidas, neste artigo, ancoram-se na tese de doutorado “Rememoração/comemoração: prática discursiva de constituição de um imaginário urbano”, orientada pela Profa . Dra.. Amanda Eloina Scherer (PPGL/UFSM), defendida em junho de 2008.

Professora do Departamento de Letras (DELET) da Universidade Estadual do Centro-Oeste UNICENTRO- PR. Campus Santa Cruz: Rua Salvatore Renna - Padre Salvador, 875, Guarapuava-PRBrasil, CEP 85015-430, Cx. Postal 730. Fone: 55-0xx42-36211000. E-mail: maria.cleci@terra.com.br
} 


\section{CONSIDERAÇÕES INICIAIS}

Neste artigo, nosso enfoque é a rememoração/comemoração como noções que funcionam juntas no eixo da formulação pela memória discursiva. Para dar conta desse objetivo, estruturamos o texto em quatro partes. Na primeira, abordamos a rememoração e a comemoração como noções advindas da História e da Antropologia nos funcionamentos e definições dadas nesses domínios do conhecimento. Em seguida trabalhamos as duas noções na teoria do discurso: a rememoração que entendemos como discurso de, na segunda parte e a comemoração como discurso sobre, na terceira parte. $\mathrm{Na}$ quarta parte enfocamos a rememoração/comemoração como prática discursiva, bem como os procedimentos discursivos de constituição do sentido desse discurso no espaço urbano pela noção de memória discursiva, espaço da formulação, onde a atualidade (eixo horizontal) e a memória (eixo vertical) se imbricam.

Os procedimentos que entendemos como prática discursiva constitutiva de um imaginário urbano, no discurso de rememoração/comemoração, são aqueles observados no corpus analisado em nossa tese, em que o espaço urbano delimitado é Cruz Alta, uma cidade do interior do Rio Grande do Sul, que se representa para dentro e fora dos seus limites como “a terra de Érico Verissimo”, constituindo-se como igual ou semelhante a pelos discursos que circulam na cidade e legitimam essa representação. $\mathrm{O}$ objeto de análise é o discurso de rememoração/comemoração em torno de Érico Verissimo, em um recorte temporal que vai de 1969 a 2006.

Estruturamos a análise a partir de dois eixos. O primeiro constitui-se dos procedimentos de “fazer-crer”, descritos por De Certeau (1994), como formas de “fazerver” e compõe-se do mobiliário social urbano da cidade (imagens e placas, que funcionam como textos) e o segundo, de textos que encaminham para o discurso de rememoração/comemoração no espaço urbano (o lugar de memória) advindos dos lugares que o sustentam, quais sejam: o museu (lugar que organiza o que pode e deve ser dito em torno do escritor), a Universidade de Cruz Alta, o Poder Público e a Mídia.

Os conceitos de espaço urbano, cidade e de imaginário urbano em nossa investigação são aqueles trabalhados por Orlandi (2001, 2003, 2004a, 2004b). Definimos a cidade como um texto que se dá a ler, apresentando-se, às vezes, como uma página em branco, e em outras, como uma página preenchida, que encaminha para a saturação, pelo efeito de evidência e de homogeneidade. 


\section{REMEMORAÇÃO E COMEMORAÇÃO}

As reflexões em torno da rememoração e da comemoração ancoram-se na noção de comemoração a partir dos historiadores, especialmente de Nora, em seus vários textos. Essas noções, na História e na Antropologia, assinalam a passagem do histórico ao rememorativo e do rememorativo ao comemorativo, como o espaço em que a memória se constitui em História. Nesses lugares as duas noções recobrem-se. A primeira - rememoração - apesar de não ser abordada, sustenta a comemoração, como o que é digno de ser lembrado. Segundo Catroga (2001: 22), na História e na Antropologia, a rememoração aproxima-se da recordação do passado, que se subordina “ao princípio de realidade, o que exige que as evocações, apesar de conjugarem um tempo passado (anterioridade), mobilizem argumentos de veridição, tendo em vista garantir a fidelidade do narrado [...]”. Diante disso podemos dizer que a memória constitutiva da rememoração é aquela que significa para os sujeitos sociais, do contrário, ela não faria parte da comemoração.

A comemoração, entretanto, é freqüentemente referenciada nesses domínios, principalmente na França, em relação à Revolução Francesa, como acontecimento sócio-político reconhecido como digno de celebração e que, de acordo com Nora (1992), foi um dos eventos que desencadeou a “Era das Comemorações”, como o lugar da celebração. Nora (id.) desenvolveu a noção lugar de memória para funcionar, em relação aos discursos de comemoração, como o lugar da crítica, buscando quebrar o tom celebrativo. Isso no momento Histórico em que o Estado tomava para si a responsabilidade comemorativa e as sociedades referenciavam a memória e não a História. A possibilidade de a memória - da ordem do vivido - extinguir-se juntamente com as comunidades que a mantinham fez com que lugar de memória se fizesse necessário, como arquivo, para que a memória pudesse transformar-se em História, como continuidade e como estabilidade, o que a institucionalizaria. No entanto, segundo Nora (ibid.), o lugar de memória, que deveria funcionar como uma contra-memória, tornou-se ele próprio um instrumento de comemoração.

Nora (1984, 1992, 1993) salienta que a comemoração, inicialmente desencadeada pelo Estado, deslizou para o privado, instaurando a celebração de nomes e 
de acontecimentos referentes às memórias de pequenas cidades e comunidades pela proliferação de museus e monumentos, como guardadores de memórias, como objetos culturais, que funcionaram como relíquias, próprias da Era da Patrimonialização.

Nora (id.) sinaliza para a impossibilidade de o Estado ou de as instituições determinarem o que é comemorado. Nesse sentido, classifica as comemorações em duas tipologias: a voluntária e a involuntária. No seu ponto de vista, a voluntária seria organizada e determinada pelas instituições, as quais priorizam o "espetáculo” e se constituem por repetições a partir de slogans, pela fabricação de acontecimentos e narrativas ritualizadas. A comemoração em torno da Revolução Francesa seria voluntária, deliberada. Mesmo assim, a França comemorava, simultaneamente, os ideais de liberdade, igualdade e fraternidade (próprios da Revolução Francesa) e também a dinastia dos reis capetianos. Com isso Nora (id.) sinaliza para as divisões, tensões e contradições que habitam a comemoração, fazendo com que coexistam no mesmo espaço a celebração e a crítica.

O acontecimento "Maio de 68” é apontado por Nora (ibid.) como uma comemoração involuntária, não regida pelo Estado. Neste tipo de comemoração, as instituições não participam dos ritos de comemoração, uma vez que estes fazem retornar discursos que as instituições buscam apagar e silenciar. Nesses eventos comemorativos, segundo o mesmo autor, há a apropriação da memória pela História pela proliferação de movimentos identitários sociais e políticos que contribuem para a afirmação da cidadania, instaurando a crítica em relação aos valores que se inscrevem na história oficial, que interessam ao Estado cristalizar e aos interesses comemorativos involuntários, apagar.

Davallon (1993/1999) enfoca a comemoração, assim como Nora, em torno da Revolução Francesa, mas a vê como a oportunidade de “olhar” criticamente o passado por meio de uma leitura simbólica do fato social comemorado. Para ele, a comemoração decorre de um jogo político ligado a fatos sócio-históricos, aos quais os sujeitos da formação social filiam-se ou não. Isso significa que ela não atinge a todos os sujeitos sociais da mesma forma, alguns se engajam e participam desses ritos, mas parte dos sujeitos se desinteressa. Assim, a comemoração desencadeia, ao mesmo tempo, a aceitação e a crítica e, por isso, pode ser abordada pela dimensão estratégica e pela dimensão simbólica, com conseqüências conjunturais e estruturais.

A dimensão estratégica diz respeito ao planejamento e desenvolvimento dos ritos comemorativos e, por isso mesmo, instaura conflitos e contradições próprias da 
vida pública, pela impossibilidade de unanimidade e de congelamento dos sentidos. A comemoração, na perspectiva de Davallon (1999), significa pelo que é vivo nas formações sociais, constituindo-se como a refundação do passado. A Revolução Francesa, de acordo com o autor, configura-se como o mito da instauração de uma sociedade nova, por meio do gesto fundador instaurado pela Declaração dos Direitos Humanos, que inaugura a possibilidade de uma sociedade de direito, o que significa dizer que essa dimensão referenda os ritos comemorativos e pauta-se pela aceitação, que estreita os laços de identificação entre os sujeitos da formação social e o objeto ou evento comemorado. A dimensão simbólica refere-se à própria análise dos ritos comemorativos em suas conseqüências políticas e se concentra no seu caráter ritualístico e institucional, instaurando a crítica, porque quebra o tom celebrativo da comemoração.

Davallon (ibid.), em relação aos ritos comemorativos, chega a três conclusões. A primeira é que esses ritos criam e materializam uma rede identitária entre os sujeitos da formação social. A segunda é que a ordem social visibilizada não representa a realidade comum à formação social, uma vez que a representação do tempo e do espaço por meio de ritos escapa à lógica do verdadeiro e do falso, pois pertence à lógica da figurativização, na qual os contrários coabitam, os elementos fundem-se, condensam-se, podendo ser vistas como um modo de representação da formação social e do que é comemorado nela. Nesta perspectiva, os ritos comemorativos subordinam-se a regras determinadas por um contrato social, que se funda na experiência humana, demonstrando que a lógica da figurativização e a experiência comum à formação social servem de fundo para a produção da significação. A terceira conclusão apontada por Davallon (op. cit.) é que todas essas práticas simbólicas e políticas de agregação sustentam-se pela produção de objetos simbólicos, que comportam traços identitários que ligam o nome ou o evento celebrado à formação social.

Esses objetos integram a prática simbólica e fornecem a representação da cerimônia que vivifica a memória. O que era objeto da História, pela comemoração, ressignifica-se como memória coletiva de grupos, podendo constituir arquivo, não como campo de documentos, mas como objeto cultural que representa em si mesmo os conteúdos imaginários que compõem os objetos culturais, tomados como documentos históricos constitutivos da herança legada a gerações futuras. Em relação à memória social, essa herança não é da mesma ordem da herança familiar, pois pertence ao coletivo da formação social. 
Segundo Catroga (2001: 44), os objetos culturais são dados como aquilo que passa de pai para filho pela rememoração e pela comemoração, como procedimentos ligados à memória social, que sobredetermina os ritos comemorativos. Nesse sentido, o que emerge da memória é "uma representificação, feita a partir do presente e dentro de uma tensão tridimensional do tempo” (id.: 46) e retorna de acordo com as emergências do presente, conduzindo a um tempo futuro, ao devir.

A comemoração, nessa perspectiva, tem como contra-face a rememoração e se caracteriza pela contradição. Organiza-se por meio de uma narrativa aparentemente coerente, que apaga “os buracos negros deixados pelo esquecimento” (ibid.: 46). Podemos dizer que a recordação viabiliza a comemoração e subordina-se ao princípio de realidade, aos conhecimentos distribuídos socialmente pelas instituições, os quais, segundo Berger e Luckmann (2007), estruturam as sociedades humanas pela linguagem. O efeito de realidade decorre da datação e da institucionalização do discurso. Por meio da rememoração, o que retorna do passado para o presente é o que é tido como o melhor para ser celebrado pelos sujeitos das formações sociais.

As relações estabelecidas entre a rememoração e a comemoração têm origem na História e na Antropologia, especificamente nos textos de Nora (1984, 1992, 1993), Davallon (1993, 1999) e Catroga (2001). Enfocamos a rememoração/comemoração no espaço urbano na perspectiva do discurso, o que exigiu deslocamentos e transformações, sendo que a mais importante delas é tomar o sujeito não como ator social, mas como posição em uma formação discursiva, que determina o que ele pode ou deve dizer a partir da posição que ocupa e do lugar de onde fala. Nessa perspectiva, essas noções constituem-se como um processo discursivo, definido por Pêcheux (1997: 161) como “o sistema de relações de substituições, paráfrases, sinonímias [...] que funcionam como elementos lingüísticos - 'significantes' - em uma formação discursiva dada”. Nesse processo, enquanto prática, importa saber “como o texto significa”, e não os conteúdos abordados nele.

A rememoração/comemoração articulada em torno do imaginário urbano, cujo objeto é o discurso da cidade de Cruz Alta sobre Érico Verissimo, em nossa interpretação, vai funcionar a partir da memória em duas dimensões: a vertical e a horizontal. A dimensão vertical - eixo das seleções - representa o já-dito e significado antes em outro lugar, que retorna ao eixo da formulação pelo interdiscurso, como préconstruído, segundo Pêcheux (1997: 171), “aquilo que todo mundo sabe”. A dimensão horizontal - eixo das relações - é o lugar da linearização do dizer - representa a 
atualidade, o fio do discurso, que abarca, em uma mesma rede de formulações, discursos que retornam, às vezes, re-significados pelo processo polissêmico, e, em outras, como pura repetição. Nesse processo, as redes parafrásticas podem solidificar o mesmo, ou romper com a estabilidade e instaurar o novo.

\section{REMEMORAÇÃO: DISCURSO DE}

A rememoração, na perspectiva da teoria do discurso, funciona como espaço discursivo, nos termos de Pêcheux (1983/2002), e como domínio de memória, nos termos de Courtine (1981). Por esse olhar, observamos o funcionamento dos préconstruídos (pelos processos de articulação e encaixamento), em que o interdiscurso retorna como discurso transverso e regula para o sujeito enunciador as condições de produção do discurso e o modo de apresentação dele. A rememoração, como memória, ancora o discurso de comemoração, dando visibilidade, pela formação discursiva, ao sujeito interpelado pela ideologia e atravessado pelo inconsciente. Ela é constitutiva da memória do espaço urbano, instaurando-se pela urgência da formação social em comemorar. Podemos dizer, em relação a isso, que a rememoração fornece o modo de funcionamento da comemoração pelos gestos e rituais que se materializam no discurso como o “fazer memória” pela institucionalização e pela legitimação da celebração de nomes ou eventos significativos para os sujeitos/cidadãos que habitam o espaço urbano.

A rememoração, de um lado, fornece ao domínio da atualidade os vestígios de um passado que retorna como recordação e, de outro, legitima a interpretação desses vestígios pelos valores sociais do presente. Sua função é instaurar e sustentar a comemoração e os discursos que a materializam. Nesse movimento, conjuga representação-interpretação e o devir, podendo ser vista, ao mesmo tempo, como gesto de recordação, de atualização e de prospecção, recobrindo o passado, como tempo ideal, o presente como o paradigma para a interpretação do passado, e o futuro, como um devir, que se constitui pelo que é comemorado no espaço das cidades.

A memória, apesar de comportar a falta e a falha, atualiza-se e é sustentada por discursos que retornam e pelo lugar de memória, em seu duplo funcionamento: como lugar que guarda vestígios dos objetos culturais que os rituais de comemoração convocam e celebram, e como o lugar em que esses objetos são ressignificados, não somente como rastros do passado, mas como um movimento contraditório de interpretação desse passado em função de um presente e de um futuro. A rememoração 
não se lineariza no fio do discurso, ela é um efeito de memória, que sustenta e ancora o dizer no eixo da formulação. É a dimensão não-linear do dizer, que irrompe no eixo da formulação, como discurso transverso, fazendo retornar discursos que representam não só o presente cultural do espaço urbano, mas também a história e a memória desse espaço e dos sujeitos que o constituem e são por ele constituídos.

Nessa perspectiva, a rememoração funciona duplamente, como memória e como discurso fundante. Como memória, materializa-se no fio do discurso pelo efeito do discurso transverso, que ocorre pelo atravessamento no intradiscurso de discursos advindos de tempos e lugares outros, encaminhando para efeitos de sentido que rejeitam a homogeneidade e fazem retornar discursos autorizados, como uma das formas de institucionalizar o dizer, legitimando-o ${ }^{2}$. Já como discurso fundante, a rememoração é o discurso que retorna e sustenta, no intradiscurso, os dizeres, dotando-os de efeitos de verdade e de pertencimento. Assim, duas posições sustentam a nossa reflexão.

A primeira é que a comemoração emerge de um discurso de, como memória, a qual, segundo Pêcheux (2002: 56), “[...] é necessariamente um espaço móvel de divisões, disjunções, de deslocamentos e de retomadas, de conflitos e de regularização [...] Um espaço de desdobramentos, réplicas, polêmicas e contra-discursos”. A memória, nesse sentido, não é plana, nem homogênea, não comporta a unanimidade, mas a diferença e a ruptura com o mesmo, instaurando novos sentidos. De acordo com Pêcheux (1997), o sentido das palavras, proposições e enunciados são determinados pelos sujeitos, a partir da filiação deles a formações discursivas, as quais, segundo Courtine e Marandin (1980: 24), são heterogêneas em si mesmas, isto é, não se fecham, mas se constituem "como fronteiras que se deslocam em função da luta ideológica”, sinalizando que a FD está aberta a saberes de outras FDs, que preenchem os furos que a constituem. No texto Discurso, Estrutura ou Acontecimento?, Pêcheux relaciona o sentido à filiação dos sujeitos a espaços de memória que os enunciados fazem trabalhar, referendando o não fechamento das FDs e, conseqüentemente, do sentido.

Como discurso de, a rememoração instaura-se se no espaço do “já-dito e significado antes em outro lugar”, cujo retorno ocorre pela repetição, que de um lado estabiliza os sentidos e, de outro, instaura o novo. Constitui-se por meio de um processo parafrástico, pelo qual, segundo Orlandi (2002: 36), “em todo o dizer há algo que se

\footnotetext{
${ }^{2}$ Cf. Pêcheux (1997: 159), esses lugares se constituem "sob a evidência da constatação que veicula e mascara a norma identificadora”, a partir da qual o sujeito se reconhece e reconhece também os lugares institucionais.
} 
mantém, isto é, o dizível, a memória”. Podemos dizer que é pela rememoração, enquanto discurso de, que os sujeitos filiam seu dizer a determinadas FDs e falam "com palavras já-ditas” (id.: 36), que reinscrevem o dizer no mesmo, cristalizando sentidos ou instaurando o diferente nesse mesmo.

A rememoração é da ordem do não-totalmente inconsciente, uma vez que as recordações ou esquecimentos não fazem parte de escolhas, mas de desejos e de demandas do sujeito e da formação social. A demanda e o desejo relacionam-se à identificação do sujeito consigo mesmo, com o outro (com “o” minúsculo) e também com o Outro (com “o” maiúsculo), segundo Pêcheux, (1997: 167) numa ordem em que “o efeito-sujeito e o efeito de intersubjetividade são contemporâneos e co-extensivos”.

A segunda posição é que a rememoração constitui-se de um texto fundante. Essa segunda modalidade de funcionamento da rememoração nos permitiu dizer que a rememoração/comemoração é uma prática discursiva constitutiva de um imaginário urbano. Nesse caso, o texto autobiográfico, de Érico Verissimo, Solo de Clarineta I, seria um dos textos fundantes, na medida em que esse texto é, em si mesmo, uma rememoração em torno do espaço urbano e do sujeito/objeto rememorado nesse espaço. Nesse sentido, instaura-se a partir de um sujeito desejante, que segundo Lacan (1985) estrutura-se pela falta e pela falha. Por meio desse conceito, é possível compreender, de um lado, como, pela linguagem, o sujeito urbano revela o desejo de identificação a um sujeito imaginário, que é ao mesmo tempo, como salientamos, a causa do desejo (objeto a) e também o que falta (objeto do desejo) no espaço imaginário da cidade.

Nesse funcionamento, o sujeito desejante constitui-se pelo efeito de espelhamento, procedimento pelo qual os sujeitos "se vêem" e "vêem” o espaço urbano pela imagem do outro, tomado como ideal de eu. Henry (1992: 176) refere-se ao sujeito desejante como o efeito de "estendimento" do inconsciente ao imaginário do sujeito. A discordância entre o eu-ideal (sujeito da enunciação) e o ideal de eu (instância do interdiscurso e do inconsciente) provoca o desejo, que pode chegar ao desejo sem controle. Pela rememoração, o sujeito imaginário, que emerge como memória, representa os sujeitos urbanos e a imagem que eles fazem de si mesmos por esse processo de espelhamento, em que um constitui o outro e é por ele constituído.

A rememoração ocupa, portanto, o lugar do já-dito e é da ordem da estabilidade. Como memória, materializa-se pelas repetições, que, pelo processo parafrástico, formam redes, as quais irrompem no fio do discurso, como o lugar em que as repetições sintagmatizam-se e constituem o mesmo ou rompem essa rede e instauram o diferente. 
O mesmo ou o diferente dependem da filiação do sujeito a FDs ou a lugares que legitimam os dizeres. Dissemos, então, que a rememoração ocorre no eixo da verticalidade e irrompe no eixo da horizontalidade, pelo interdiscurso, como um efeito sobre si mesmo, segundo Pêcheux (1997: 167), “uma interioridade inteiramente determinada como tal 'do exterior'”. É pela exterioridade, portanto, que a rememoração funciona como um espaço discursivo interpretado pela força do presente.

\section{COMEMORAÇÃO: DISCURSO SOBRE}

O discurso sobre, a comemoração, sustenta-se em um discurso de e materializase na dimensão linear do dizer, o fio do discurso. Segundo Orlandi (1990), é uma modalidade discursiva que institucionaliza os sentidos. Um dos efeitos do discurso sobre é, de acordo com Mariani (1999), tornar objeto o nome ou evento sobre o qual fala o sujeito do discurso. Trata-se de um discurso doutrinário, que fornece e impõe a realidade aos sujeitos da formação social, marcando o discurso por uma aparência de estabilidade e de homogeneidade, que aproxima o fazer discursivo do fazer histórico, na ilusão de poder realizar, segundo Pêcheux, “o apagamento seletivo da memória histórica”.

Uma das marcas do discurso sobre é a modalização deôntica do dizer, materializada, no fio do discurso, pelos verbos dever e ter, próprios dos discursos institucionais em que os sujeitos atuam como porta-vozes, isto é, falam de um lugar autorizado, em nome de, como mediadores. Segundo Conein (1980), o sujeito mediador é próprio do discurso político, onde se constitui como sujeito porta-voz, "como agente coletivo em movimento”, que exerce duas funções enunciativas: a primeira, de agente (aquele que fala em nome de) e a segunda, de mediador (aquele que realiza uma ação, em nome do coletivo que representa).

Pêcheux (1982/1990: 17) faz uso dessa noção para pensar as contradições em torno das revoluções do século XIX e XX e define o sujeito porta-voz como o sujeito que "se expõe ao olhar do poder que ele afronta, falando em nome daqueles que ele representa, e sob seu olhar. É aquele que se [...] coloca em posição de negociador em potencial, no centro visível de um “nós” em formação [...]”. O sujeito porta-voz, nessa perspectiva, circula entre três posições: a de profeta, a de dirigente e a de homem de Estado, nessa última posição, ocupa um lugar institucional. Ainda de acordo com 
Pêcheux (id.), ele se constitui como agente de contradições e deslocamentos, porque circula entre o mundo que existe e a possibilidade de existência de "um outro mundo".

O sujeito porta-voz no discurso de rememoração/comemoração é o sujeito autorizado a dizer o que diz. Assume o lugar de sujeito enunciador, conforme Pêcheux (1997a), instituindo-se como o responsável pelo dizer. O sujeito, no discurso sobre, é da ordem do não-totalmente consciente. O dizer materializa-se na tensão entre o já-dito do interdiscurso, como o que significa antes em outro lugar e retorna pelo efeito do discurso transverso, re-inscrevendo o dizer no eixo da formulação. O sujeito é responsável pelo dizer institucionalizado, e a partir do lugar de memória, institui um “nós” coletivo que emerge dos lugares que sustentam a rememoração/comemoração como o lugar, que organiza, atualiza e distribui os dizeres e saberes que podem/devem entrar na ordem do discurso.

\section{REMEMORAÇÃO/COMEMORAÇÃO: PRÁTICA DISCURSIVA}

Neste artigo, enfocamos a rememoração e a comemoração, em um primeiro momento, a partir da História e da Antropologia e depois cada uma delas, em seu funcionamento discursivo. Nessa perspectiva, a rememoração como discurso de sustenta a comemoração - o discurso sobre - que institucionaliza o dizer. Sinalizamos, também, desde o início, que nesta quarta parte, explicitaríamos a rememoração/comemoração, que grafamos juntas, como uma noção, em que a rememoração nos seus dois funcionamentos (memória e discurso fundante) é tomada como o que se repete e inscreve o dizer em redes de memória na comemoração - atualidade.

No eixo da formulação, tendo como fio estruturante a memória discursiva, essas duas noções não se separam, pois memória e atualidade constituem uma materialidade de sentido. Não há como separá-las, por isso grafamos com travessão. O interdiscurso, que corresponde ao que já-dito significa no eixo da atualidade, mas nem sempre se lineariza, retornando como discurso transverso.

A memória discursiva é mobilizada diferentemente por Pêcheux (1999), Orlandi (2002a, 2003, 2004) e Courtine (1981). Para Pêcheux (1999: 52), os enunciados que constituem a memória discursiva fazem sentido no intradiscurso porque pertencem à ordem do já-dito, ao domínio do saber. É, enfim, “a condição do legível em relação ao próprio legível” para a leitura de um texto como acontecimento. Já para Orlandi (2002: 31), essa noção constitui “o saber discursivo que torna possível todo dizer e retorna sob 
a forma de pré-construído, o já-dito [...] sustentando cada tomada de palavra”. Em resumo, para a autora a memória discursiva sinaliza para o interdiscurso.

Courtine (1981) retomou essa noção e a relacionou à existência histórica do enunciado no seio de práticas discursivas reguladas por aparelhos ideológicos, na esteira de Foucault (1969). Para ele a memória discursiva constitui-se de enunciados que retornam e instauram a repetição ou a transformação do sentido, reinscrevendo os dizeres a domínios de memória. Nesse sentido (id.: 53), a memória discursiva comporta o interdiscurso (memória) e também os domínios da atualidade e da antecipação, instaurando “efeitos de memória” no eixo da formulação.

A memória discursiva em funcionamento no discurso de rememoração/comemoração no espaço urbano analisado constitui-se de dois eixos - o vertical e o horizontal - em um movimento em que a memória (rememoração) comporta as repetições e irrompe na comemoração (atualidade), às vezes, sustentando o mesmo e, em outras, rompendo com o já-dado, num movimento de sentidos que se relaciona a filiações e a lugares institucionais, que sustentam o lugar de memória. Dissemos isso tendo em conta que a memória discursiva não é simétrica, nem fechada e os sujeitos e as instituições, apesar dos efeitos de evidências de saturação do discurso institucional, não controlam o trabalho da memória, nem os espaços discursivos que ela reclama e faz funcionar, constituindo pelo discurso um imaginário urbano.

Como dissemos nas considerações iniciais, os procedimentos discursivos constitutivos do discurso de rememoração/comemoração no discurso urbano foram observados nas materialidades discursivas analisadas em nossa tese. Para isso recortamos um espaço comemorativo - Cruz Alta - em um espaço temporal que se estende de 1969 a 2006, que nos possibilitou observar os movimentos desse discurso em torno de Érico Verissimo, como sujeito idealizado nesse espaço. Nosso corpus abarcou diferentes materialidades, dentre as quais analisamos: a placa de boas-vindas afixada nas rodovias que dão acesso à cidade, as imagens de Cruz Alta hoje (prédios com o nome do escritor, de suas obras e personagens), dois documentários (um de inauguração do museu, realizado pela RBS TV e outro em que o responsável pelo Museu apresenta o escritor aos visitantes, realizado pela TV Unicruz), peças publicitárias, um painel colocado no portal da prefeitura e outro que circulou no vidro traseiro de um coletivo urbano de Cruz Alta ${ }^{3}$.

\footnotetext{
${ }^{3}$ As materialidades analisadas podem ser visualizadas em nossa tese de doutorado, disponível no banco de teses da UFSM.
} 
Analisamos essas materialidades em torno de dois eixos: o de "fazer crer", descrito por De Certeau (1994), pelos procedimentos de “fazer-ver”, em relação ao que ele chama de "imaginário do ver” e o de lugar de memória ${ }^{4}$, constituído pela própria rememoração/comemoração e pelos lugares institucionais que o atualizam e sustentam. Esse lugar de memória é sustentado por outros lugares, quais sejam: museu Érico Verissimo (como o lugar que organiza os demais lugares), a Unicruz (Fundação Universidade de Cruz Alta), o Poder Público da cidade e a mídia, que organiza o imaginário urbano.

O primeiro eixo, em que analisamos os procedimentos de "fazer-crer", satura o discurso, fazendo "ver” por que Cruz Alta se representa para dentro e fora de seus limites como "a terra de Érico Verissimo”, compõe-se de uma placa que identifica a cidade, e ao mesmo tempo e "faz-ver” pela delimitação de fronteiras a razão desta designação e imagens da cidade hoje. A primeira materialidade é essa placa, na qual estão inscritos os dizeres: “Cruz Alta: bem-vindos à terra de Érico Verissimo”. A segunda materialidade, que designamos de mobiliário social, compõe-se de prédios com o nome do escritor, de suas obras e de personagens de suas obras e faz "ver” Érico Verissimo e a cidade, pela rede de identificação “tecida” no espaço urbano, como um mesmo objeto, como se um pudesse ser lido/interpretado/compreendido pelo outro, pelas “semelhanças”, instituídas pelas relações metafóricas, sustentadas pela rememoração como memória e também como texto fundante. Os prédios e monumentos sinalizam para o escritor e para a sua obra como discurso fundante, especialmente Solo de Clarineta I, texto autobiográfico, e O Tempo e o Vento, trilogia que representa, na ordem da ficção, mais de duzentos anos de história do Rio Grande do Sul.

Em relação à rememoração/comemoração como lugar de memória, observamos que “esse lugar” funciona em rede com outros lugares e constitui de um lado o sujeito rememorado/comemorado, e, de outro, o imaginário urbano por um processo metafórico e não metonímico. Dissemos isso porque os valores que o representam pela sua obra e pela memória são imaginariamente transferidos ${ }^{5}$ aos sujeitos/cidadãos do espaço urbano, num processo em que um é o simulacro do outro. Assim, o discurso de rememoração/comemoração pelos efeitos de identificação e de pertencimento constitui

\footnotetext{
${ }^{4}$ Neste trabalho o lugar de memória é lugar em que a FD dominante (a da rememoração/comemoração) organiza, atualiza e faz circular o que pode e deve ser dito ou ritualizado em torno do sujeito idealizado, constitutivo do imaginário urbano, no caso por nós analisado, o de Cruz Alta/RS.

${ }^{5}$ A transferência a que nos referimos advém da psicanálise e significa o processo pelo qual os desejos se atualizam sobre objetos do desejo (no caso o objeto da rememoração/comemoração).
} 
o imaginário urbano pela rememoração - memória do sujeito idealizado - e pelo discurso fundante - o que retorna e se repete - e produz, segundo Courtine (1999), um preenchimento e um efeito de consistência no interior do formulável, saturando e homogeneizando o discurso, pela solidificação da imagem do sujeito/objeto da comemoração pelo discurso como prática discursiva.

As análises das materialidades que compuseram o corpus discursivo da nossa tese de doutorado em relação ao lugar de memória - a rememoração/comemoração e os lugares que a sustentam/sinalizam para os procedimentos que constituem os efeitos descritos acima, entre os quais destacamos as palavras de ordem, que encaminham para formas estabilizadas de "preservar memória” e determinam o que pode e deve ser dito ou feito para transformar esse nome em História. Entre os enunciados que funcionam nessa direção, destacamos “Preservar para lembrar”, em que as expressões deônticas do dizer retornam pelo efeito do discurso transverso.

A definição é um dos procedimentos de “fazer-crer” porque "faz-ver” o sujeito que povoa o imaginário urbano. Observamos o funcionamento desse procedimento pela estrutura oracional predicativa (X é...) utilizada para definir o escritor, nesse discurso, como "filho mais ilustre”, “cidadão de todos os continentes”, “nosso maior bem cultural”, "herança que queremos dividir com todos", "nosso maior contador de histórias”. Todas essas definições encaminham para idealidade. Segundo De Certeau (1992: 290), a citação “é a arma absoluta de fazer crer, como ela ‘joga’ com aquilo que o outro supostamente crê, é portanto o meio pelo qual se institui o real”. Nos textos analisados a citação ocorre pela retirada de fragmentos da obra do escritor, em que a personagem fala da casa em que ele nasceu e da importância dessa casa na sua vida, para “fazer-crer” e também “fazer-ver” a importância histórica da casa no espaço urbano de Cruz Alta. A citação contribui para a construção de "simulacros” e, com isso, de "realidades imaginárias. Além dos procedimentos descritos, ressaltamos a repetição de uma mesma imagem, no caso do escritor, e também da sua assinatura. Para analisar o efeito discursivo delas no discurso de rememoração/comemoração trabalhamos com o conceito enunciado-imagem, para argumentar que as imagens, assim como os enunciados verbais, comportam memórias e significam diferentemente em cada formulação, haja vista a sua relação a sujeitos e a inscrição deles a domínios de memória. 


\section{CONSIDERAÇÕES FINAIS}

Concluir é sempre difícil, especialmente quando há muito a dizer, e não há tempo nem espaço para fazê-lo. De qualquer forma, é sempre impossível fechar um texto, tomado como discurso, porque ele se move, instaura a repetição e ao ser repetido, legitima o já-dito e significado e às vezes, segundo Courtine (1981), transforma ou apaga o já-dito, fazendo trabalhar espaços de memória, nem sempre previstos pelas instituições, uma vez que os efeitos de memória e o movimento que se dá entre o espaço da rememoração e da comemoração nem sempre são recuperáveis.

A cidade, nesta perspectiva, é um grande texto e se constitui pelo equívoco de ser, ao mesmo tempo, uma página em branco, a ser preenchida, que encaminha para o novo e, outras vezes, como uma página preenchida, que encaminha para o mesmo, sem o diferente, cuja leitura vislumbra o “inteligível”, talvez o “interpretável”, mas nem sempre o “compreensível”. No entanto, apesar dos efeitos de evidência, dos simulacros, das saturações, o espaço urbano não se deixa aprisionar por fronteiras porque o “mesmo" dizer encaminha para sentidos outros, faz trabalhar outros espaços de memória, apesar e acima das instituições.

As análises das materialidades discursivas sinalizam para o fato de que o esforço para "fazer-crer" pelo "fazer-ver" também deixa "furos” e com isso a possibilidade de os sentidos deslizarem, rompendo a rede “imaginária” que as instituições urbanas esforçam-se para solidificar. Apesar de, no fio do discurso, as palavras de ordem, as citações, as definições e as repetições de enunciados/imagens encaminharem a solidificação dessas redes, constituindo o mesmo, sem o diferente, mas também a falta e a falha, fazendo retornar outros discursos, que instauram o novo.

Nesse sentido, o que se pode dizer, para de alguma forma concluir a reflexão em torno da rememoração/comemoração no espaço urbano, é que “os furos” permanecem, apesar da aparente saturação do discurso. A citação, como procedimento de "fazercrer”, nem sempre instaura a repetição, por vezes, ela faz emergir outra citação e com ela outros discursos. No espaço entre uma definição e outra, apesar das evidências de complementaridade, os furos persistem, as palavras de ordem se dispersam, os enunciados-imagens deslocam sentidos, fazendo com que "a maior herança cultural” passe a ser “o nosso maior contador de histórias”. 
Enfim: rememoração (memória e discurso fundante) e comemoração (atualidade) no fio do discurso se fundem e sinalizam para a quase impossibilidade de estabelecer fronteiras entre o que é memória e o que é atualidade.

\section{Résumé}

À ce article propose une réflexion sur la remémoration/commémoration dans l'espace urbain au moyen de trois notions: remémoration, commémoration et lieu de mémoire. Le but est de theorizer sur la paire remémoration/commemoration en tant que notions articulées par celle de m'memoire discursive. Les trois notions en question sont déplacées des domaines de l'Histoire et de l'Anthropologie vers le domaine de l'Analyse du Discours. La remémoration, déjà dans les deux primiers domains, est traité comme souvenir; la commémoration lieu de célébration et le lieu de mémoire est introduit par Pierre Nora (1992) pour fonctionner comme contre-mémoire, le lieu de critique. Discursivement, la remémoration discours de - recouvre et fonctionne comme mémoire alors que la commémoration - discours sur - comme intradiscours. Dans l'axe de la formation, elles fonctionnent ensemble à partir de la mémoire discursive constitutive du discours urbain.

Mots-clés: discours urbain, mémoire, remémoration/commémoration

\section{REFERÊNCIAS BIBLIOGRÁFICAS}

BERGER, P.; LUCHMANN, T. A construção social da realidade. 27. ed. Trad. de Floriano de Souza Fernandes. Petrópolis-RJ: Vozes, 2007.

CATROGA, F. Memória e história. In: PESAVENTO, S. J. (org.) Fronteiras do milênio. Porto Alegre-RS: Editora da UFGRS, 2001.

CORTEN, A. Décrire um evénement politique. Université de Paris VIII. In: Le Colloque “Matérialités Discursives”. Organisé par CONEIN, B.; COURTINE, J.-J. et al. Nanterre, 24-25-26 avril, 1980.

COURTINE, J.-J.; MARANDIN, J.-M. Quel objet pour l'analyse du discours? In: Le Colloque “Matérialités Discursives”. Organisé par CONEIN, B.; COURTINE, J.-J. et al. Nanterre, 24-25-26 avril, 1980.

Analyse du discours politique (le discourse communiste adressé aux chrétiens). Langage 62. Paris, juin 1981.

DAVAlLON, J.; DUJARDin, P.; SABATIER, G. (orgs.) Politique de la mémoire. In: Comemorer la revolution. Lyon: Presses Universitaires, 1993. Imagem, uma arte da Memória. In: ACHARD, P. et al. Papel da memória. Trad. de José Horta Nunes. Campinas-SP: Pontes, 1999.

DE CERTEAU, M. A invenção do cotidiano. 1. Artes de fazer. Trad. de Ephraim Ferreira Alves. Petrópolis-RJ: Vozes, 1994.

HENRY, P. A ferramenta imperfeita: língua, sujeito e discurso. Trad. de Maria Fausta P. de Castro. Campinas-SP: Editora da Unicamp, 1992. 
LACAN, J. O Seminário - livro 2: o eu na teoria de Freud e na técnica da psicanálise. Trad. de Marie Christine Lasnik et al. Rio de Janeiro-RJ: Jorge Zahar, 1985.

MARIANI, B. S. Discurso e instituição: a imprensa. Revista Rua. V. 5. Campinas-SP: Labeurb/Nudecri - Unicamp, 1999.

NORA, P. Entre mémoire et histoire. La problématique des lieux. In: Les lieux de mémoire. Vol I - La Republique, pp. XV-XLII, Paris: Editions Gallimard, 1984.

L’Ere des commémorations. Vol. III, Paris: Editions Gallimard, 1992, p. 687-715.

. Entre a memória e a história: a problemática dos lugares. Projeto História. Trad. de Yara Aun Khoury. São Paulo-SP: PUC/SP, dez. de 1993.

ORLANDI, E. P. Discurso do confronto: velho e novo mundo. São Paulo-SP: Cortez, 1990.

. (org.) Discurso fundador: a formação do país e a construção da identidade nacional. 2. ed. Campinas-SP: Pontes, 2001.

Análise de Discurso: princípios e procedimentos. $4^{\mathrm{a}}$. ed. Campinas-SP:

Pontes, 2002.

. (org.) Para uma enciclopédia da cidade. Campinas-SP: Pontes, 2003.

. Interpretação: autoria, leitura e efeitos do trabalho simbólico. Campinas-

SP: Pontes, 2004a.

. Cidade dos sentidos. Campinas-SP: Pontes, 2004b.

PÊCHEUX, M. Delimitações, inversões e deslocamentos. Trad. de José Horta Nunes. In: Cadernos de Estudos Lingüísticos (19). Campinas-SP: Editora da Unicamp, 1990, p. 7-24.

. Semântica e discurso: uma crítica à afirmação do óbvio. Trad. de Eni Orlandi et al. 3. ed. Campinas, SP: Editora da Unicamp, 1997.

. O discurso: estrutura ou acontecimento. 3. ed. Trad. de Eni P. Orlandi. Campinas-SP: Pontes, 2002. 


\section{Revista do Laboratório de

\section{Para citar essa obra:}

VENTURINI, Maria Cleci. Rememoração/Comemoração no Discurso Urbano. RUA [online]. 2009, no. 15. Volume 1 - ISSN 1413-2109

Consultada no Portal Labeurb - Revista do Laboratório de Estudos Urbanos do Núcleo de Desenvolvimento da Criatividade

http://www.labeurb.unicamp.br/rua/

\section{Laboratório de Estudos Urbanos - LABEURB}

Núcleo de Desenvolvimento da Criatividade - NUDECRI

Universidade Estadual de Campinas - UNICAMP

http://www.labeurb.unicamp.br/

\section{Endereço:}

Rua Caio Graco Prado, 70

Cidade Universitária “Zeferino Vaz” - Barão Geraldo

13083-892 - Campinas-SP - Brasil

Telefone/Fax: (+55 19) 3521-7900

Contato: http://www.labeurb.unicamp.br/contato 